\title{
Banking Sector Asset Concentration Risk
}

\author{
Irina Larionova \\ Department of Financial Markets and Banks \\ Financial University under the Government of the Russian \\ Federation \\ Moscow, Russia \\ 8653@mail.ru
}

\author{
Elena Meshkova \\ Department of Financial Markets and Banks \\ Financial University under the Government of the Russian \\ Federation \\ Moscow, Russia \\ meshkova.elen@gmail.com
}

\begin{abstract}
The subject of the research is the concentration of risks related to active transactions of commercial banks as a factor for systemic risks of the banking sector. The purpose of the research is to work out specific measures to mitigate the banking sector's exposure to systemic risks in view of the analysis of the Russian and international risk concentration mitigation practices. The Russian banking sector remains extremely vulnerable to systemic risks. One of the material sources thereof is the concentration of banking sector assets at both micro- and macro-levels. The statistical data of international organizations suggest that among European countries having reported on such figure Russia is high on the list regarding the risk concentration. The high level of asset concentration in the Russian banking sector requires the analysis and improvement of the existing supervisory practice. This paper suggests improvements for the major risk control: putting in place a risk mitigation practice with account of credit claim quality, as well as the consideration of economic interdependency factor, to identify groups of related contractors.
\end{abstract}

Keywords-banking business; systemic risk; risk sources; risk concentration; group of related borrowers; economic interdependency

\section{INTRODUCTION}

The Russian banking sector is rather susceptible to systemic risks. One of major sources of systemic risks is asset concentration at the micro- and macro-level. The risk profile of the Russian banking sector indicates that the banking industry is still in a rather challenging situation. A threat of possible realization of systemic risks is genuine, with one of the potential sources thereof constituted by asset concentration risks.

\section{ASSESSMENT OF SYSTEMIC RISK LEVEL}

The world community has been actively searching for approaches to assess the systemic risk level of financial sector in recent years. Let us consider the most noteworthy works (from our point of view). First of all, we shall refer to a range of studies conducted by the International Monetary Fund starting from the Financial Stress Index calculation method which was published as far back as 2008 [1]. This index was calculated separately for mature and developing economies with various methodological approaches for index formation being proposed. For instance, it was proposed to use the following as sub-indices for mature economies: volatility of bank share quotations, spreads between inter-bank rates and treasury stock rates, spreads for corporate bonds, stock performance and volatility of stock performance, and exchange rate volatility. In order to form a financial stress index for developing economies, the foreign currency market contraction figure was taken into account and, on the contrary, any figures related to corporate bonds were excluded due to the underdevelopment of debt market.

R. Ranciere, A. Tornell A. and A. Vamvakidis (2010) in their work proposed to assess the value of currency mismatch reflecting risks of the global financial system [2]. Jorge A. Chan-Lau (2010) focused on the assessment of interdependency of financial institutions using the "regulatory capital charges" concept [3]. For this purpose, the author offered specific tools to make such assessment: the loan portfolio risk assessment model, network analysis and CoRisk-analysis1. Research of N. Gianni, L. Marcella (2010) examined systemic risks broken down by the actual systemic risk (GDP-at-Risk) and the financial systemic risk (FSaR) taking into account sources of the potential financial shock [4]. It was proposed to apply a VaR-model to assess risks.

The classification of existing systemic risk measurement methods has been developed and is in effect as of the moment. Let us refer to one of such - classifications offered by Giglio et al., who distinguished five primary risk measurement methods [5] [6]:

- Specific methods. The essence of the method is that firstly the individual system risk assessments are made for each bank that shall be subsequently aggregated. Examples of such models are CoVaR (Adrian, Brunnermeier (2011)), SRISK (Brownlees, Engle (2012)) and some other methods.

- Comovements measures. They enable to assess comovements between the stock performance of selected banks.

- Assessment of financial system instability. This method is focused on the identification of aggregated instability and volatility of the financial system. 
- Assessment of liquidity. The essence of the approach is alignment of the systemic event with the liquidity level in financial markets.

- Assessment methods envisaging the use of credit default swap (CDS) spreads.

Let us consider the work of L. Laeven, L. Ratnovski and H. Tong as an illustration of the specific systemic risk assessment method application (2016), which proposes to use available figures as a means for banking sector systemic risk measurement: CoVaR (assessment of conditional value at risk), and SRISK (expected capital shortfall during crisis) [7]. This model considers banking capital, funding, assets and their relation to the bank assets value as fundamental risk sources.

The IMF practice uses indicators of financial sector systemic risks as follows: assessment of macroeconomic risks, credit risk, market risks and liquidity risk, capital flow (interrelation) risk, CDS spreads of the largest banks, debt market spreads, assessment of bank management, assessment of $\mathrm{VDaX}$ index volatility [8].

The issue concerning sources of banking sector systemic risks was paid attention to in the works of national and foreign researchers: E. P. Jagityan, T. H. Lee, S. H. Chih, F. Awdeh, C. El-Moussawi, F. Machrouh, V. Andrianova, I. V. Larionova and others [9] [10] [11] [12] [13] [14]. However, one of the most important systemic risk sources that has been neglected until recently by either domestic scientists or experts in the field, in our opinion is a high level of bank asset concentration both at macro- and micro-levels. Not so many works may be mentioned which focused on the risk concentration as a material factor of bank stability. They include: M. V. Leonov, D. F. Zakirova and E. F. Zakirova, P. A. Razumovsky, M. V. Pomazanov and some other works [15] [16] [17]. Concentration risk is typically considered in the context of other factors: from the point of view of ownership or regional distribution of banks, sectoral affiliation of borrowers or interdependence thereof [18] [19] [20].

It stands to mention that one of the major conclusions resulting from the crisis of 2007 - 2009 was that banks had to constantly measure, aggregate and control risks per specific contractors or groups of related contractors for the entire range of transactions.

\section{CONCENTRATION RISK}

The Bank of Russia defines a concentration risk as a risk "arising out of the credit institution exposure to major risks which, if realized, may result in significant losses with potential threat to the credit institution solvency and its ability to continue as a going concern". However, it appears that the analysis and management of concentration risk is important not only in view of default prevention but also to manage financial results of the bank in the course of current activity. Therefore, it is deemed to be reasonable to apply an approach defining a concentration risk as a risk arising "due to unequal distribution of lending resources of the bank among its borrowers as well as excessive sectoral or regional business concentration"[21].

Risk concentration arises out of the transactions with financial instruments with identical characteristics and similarly affected by changes of economic or other conditions 2 .

We reckon that with regard to the banking sector, the asset portfolio concentration risk shall be considered both at macro and micro levels.

Risk concentration at the micro level is determined by the aggregated open position per contractor (debtor, creditor), distribution of borrowers by types of activity, breakdown of portfolio by the territory, type of instruments/transactions dealt with by the bank. As far as the macro level is concerned, concentration risk is connected to the bank transactions diversification level or, alternately, concentration of a large amount of assets of the banking sector in a number of credit institutions. The type of ownership of a credit institution shall be distinguished as another factor. For instance, if the significant share of banks is possessed by international financial groups, it cannot but result in an additional risk of banking sector instability overall due to owners' ability to affect banks' policy. A similar situation arises when the funding base of credit institutions is to a great extent formed at the expense of nondiversified sources, in particular, a significant share of funds raised with the engagement of international capital markets. Undoubtedly, the source of increased risks is also concentration of banking sector transactions in the product, sectoral and regional aspects.

If we consider the behavior of the share of major credit risks in the banking sector assets, we shall mention that such share is significant - the average value of the banks exceeds $27 \%$.

If we apply international statistics data and consider the level of major risks as against the equity capital of the banks as of the beginning of 2016, we may state that its value in Russia is one of the highest among European countries having reported on the level of such value $-254.4 \% 3$. Thus, the existing high level of risk concentration in the Russian banking sector requires to analyze and improve the existing supervisory practice.

The necessity to measure and limit the amount of major risks as against banks' capital has long been recognized by the Basel Committee on Banking Supervision. In particular, in 1991 the Committee issued supervisory guidelines to measure and control major credit risks [22]. The Core Principles for Effective Banking Supervision (Principle 19) include a requirement for the banks to have adequate policy and procedures to detect, measure, assess, monitor, report on and control the level of risk concentration. The supervisory

\footnotetext{
Pursuant to IFRS 7 "Financial Instruments: Disclosures"

International Monetary Fund. Financial Soundness Indicators. http://data.imf.org/?sk=9F855EAE-C765-405E-9C9A-A9DC2C1FEE47
} 
authorities are advised to establish prudential limits to restrict major risks4.

Finally, in 2014 the Basel Committee on Banking Supervision adopted a separate Standard for assessing and controlling large positions [23].

In accordance with this standard, the risk is deemed major, if the sum of values of all bank positions per contractor or a group of related contractors equals to or exceeds $10 \%$ of the capital of the commercial bank.

It has been determined that banks shall submit to the supervisory authorities reports of major credit risks before and after the application of risk mitigation methods. Banks shall submit reports:

- On all positions with the value of 10 or more per cent of their equity capital;

- On the list of 20 largest contractors in part of assumed risk.

The Basel Committee on Banking Supervision determined that the sum of all risks (positions) of the bank per contractor or a group of related contractors should not exceed $25 \%$ of the bank's equity capital at any time period. Such level has been decreased down to $15 \%$ for too-big-tofail banks.

This document determines clear principles for inclusion of separate companies/persons into the group of related contractors. The key criterion is a formal legal dependence; however, it is of particular importance for Russian practice that the criterion to be taken into account shall be an economic interdependency of contractors. Thus, the Standard stipulates that two or more individuals or legal entities be deemed a group of related contractors, if at least one of the below criteria is met:

- With regard to control: one of the contractors directly or indirectly controls the other;

- With regard to economic interdependency: if one of the contractors has financial problems, in particular, funding and debt repayment difficulties, the others are most likely to face problems related to funding or discharge of liabilities as a result thereof.

Upon determination of coherence based on the economic criteria, the banks shall account for a range of parameters stipulated by the standard.

The banks are advised to distinguish groups of economically related contractors based on the materiality principle, if the risk per contractor exceeds $5 \%$ of bank's capital.

A particular lesson of the crisis translated into international documents consisted in the fact that material losses of one too-big-to-fail financial institution may instigate insolvency of others with potentially disastrous

The Core Principles for Effective Banking Supervision, published by the Committee in September 2012, are accessible at www.bis.org/publ/bcbs230.pdf consequences for global financial stability. As a result, the criteria have been determined for the banks to be distinguished as too-big-to-fail banks and approaches for stricter limitation of risks for this cluster of banks have been proposed.

Russia is generally moving towards the application of international approaches in part related to the control and limitation of major risks. However, some peculiar aspects persist.

Regulatory limitation of major risks is first and foremost determined by the instruction of the Bank of Russia "On Prudential Supervision Ratios" which stipulates for mandatory compliance by credit institutions with several ratios, first of all:

- Maximum risk ratio per borrower or a group of related borrowers (H6) which is calculated as a ratio between aggregate claims to the borrower (group of related borrowers) and equity capital of top-tier bank. Regulatory level of the value is fixed at the rate of $25 \%$.

- Maximum major credit risks ratio (H7) limiting the aggregate amount of major credit risks of the bank and determining maximum ratio between the total value of major credit risks and amount of bank's equity capital. Regulatory level of the value is fixed at the rate of $800 \%$.

In accordance with Article 65 of the Federal Law "On the Central Bank of the Russian Federation (Bank of Russia)", the major credit risk is an amount of credits, guarantees and suretyships in favor of one client exceeding five per cent of the bank's equity capital, that is, we observe that the Russian regulatory authority applied ratios which are even stricter than those recommended by the Basel Committee on Banking Supervision.

The information disclosing existence of major credit risks is publicly available, and the banks submit the relevant statements to the Bank of Russia.

Meanwhile, the Bank of Russia has adopted a new form of financial statements since 2017: "Data on concentration risk" which shall include data on concentration risks for the items as follows:

- Types of economic activity;

- Geographic zones;

- Types of instruments;

- Liquidity sources.

The data on the scope of claims of the credit institution against contractors broken down by their types, the information on derivatives, the amount of credit and market risks as well as types and amounts of limits fixed by the credit institution, signal limit values and the number of violations thereof in the reporting period will be submitted per each group. Thus, the Bank of Russia plans to control the compliance of internal Bank's limits with actual 
concentration risk levels in accordance with recommendations of the Basel Committee on Banking Supervision.

As a measure to limit concentration risk on the banking sector scale the Bank of Russia adopted a regulatory document - Instruction dated July 22, 2015 No. 3737-Y "On the Methods to Determine Too-Big-To-Fail Credit Institutions" whereby the regulatory authority on a regular basis publishes the list of such institutions with a gradual aggravation of requirements to these banks for the purposes of financial stability of the sector.

\section{CONCLUSION}

Regulatory requirements of the Bank of Russia in part related to the assessment and control of major risks are developing pursuant to international approaches, in particular cases even stricter risk limitation applies. However, it shall be noted that as of the present moment only one requirement upon determination of the group of related borrowers in Russia is established with regard to the formal legal dependence. Thus, the maximum risk is fixed per one borrower or a group of related borrowers being associated, parent or subsidiary companies to each other. Unfortunately, the economic interdependency of contractors is not taken into account at the moment.

It is reckoned that the key problems related to regulatory limitation of major risks in the Russian banking sector include:

- A disputable nature of methods for regulatory risk concentration level limitation applied as of the moment: they are not associated with the credit quality of the borrower and/or group of related borrowers, there is a single risk limitation ratio at the rate of $25 \%$ of the capital and for borrowers of the first and fifth quality categories.

- Groups of related borrowers are not taken into account with regard to their economic interdependency. However, it should be noted that such interdependency is hard to establish.

- Problems upon concentration risk measurement. At the moment, regulatory practice applies simple summation methods which is not quite correct.

In consideration of the foregoing, we reckon that the practice of major risk regulation in the banking sector shall develop in the following directions:

- Introduction into the regulatory practice of major risks limitations per contractor (group of related contractors) with regard to credit quality of financial claim. Weighting factors shall apply as follows: for contractors referring to the first quality category from the risk perspective weighing factor of 0.5 shall apply, for those assigned the second quality category - 0.8 ; for the fourth and fifth categories - 1.5 .

- Establishment of the economic interdependency of contractors upon the identification of groups of related stakeholders with the changes to be introduced into the regulatory framework of the Bank of Russia.

\section{REFERENCES}

[1] World Economic Outlook, October 2008 - Chapter 4: Financial Stress and Economic Downturns, October 2, 2008. URL: http://www.imf.org/external/pubs/ft/weo/2008/02/pdf/c4.pdf

[2] R. Ranciere, A. Tornell, A. Vamvakidis, New Index of Currency Mismatch and Systemic Risk. IMF Working paper. November 2010. URL: http:// www.imf.org.

[3] Jorge A. Chan-Lau, Regulatory capital charges for too-connected- tofail institutions: a practical proposal //IMF Working paper. April 2010 URL: http: // www.imf.org.

[4] Gianni De Nicolo, Marcella Lucchetta, Systemic risks and macroeconomy //IMF Working Paper. WP 10/29. February 2010. URL: http:// www.imf.org.

[5] V. Manayev, Systemic risk measurement // Risk management in a credit institution, 2013, No. 3, pp. 105-110.

[6] S. Giglio, B. Kelly, S. Pruitt, Systemic risk and the macroeconomy: An empirical evaluation // Journal of Financial Economics, 2016, No. 119 , pp. 457-471.

[7] Luc Leaven, Lev Ratnovski, Hui Tong, Bank size, capital, and systemic risk: Some international evidence // Journal of Banking \& Finance, 2016, No. 69, pp. 25-34

[8] Financial system stability assessment, Germany. URL: http://www.imf.org/external/pubs/ft/scr/2016/cr16189.pdf

[9] E. P. Jagityan, Bank regulation reform in China: Specific aspects of regulation continuum and systemic risks // Money and Credit. 2014 No. 12 , pp. 51-62.

[10] E. P. Jagityan, Basel III in Russia: Synchronization of Regulation Reform Associated with Systemic Risks // Money and Credit. 2016. No. 7, pp. 47-58.

[11] T.-H Lee, S.-H Chih, Does financial regulation affect the profit efficiency and risk of banks? Evidence from China's commercial banks // The North American Journal of Economics and Finance, 2013, No. 26, pp. 705-724.

[12] A. Awdeh, C. El-Moussawi, F. Machrouh, The effect of capita requirements on banking risk // International Research Journal of Finance and Economics, 2011, no. 66, pp. 133-146.

[13] V. Andrianov, Systemic risks of credit and banking system of Russia // Society and Economics. 2014. No. 1, pp. 71-112.

[14] I. V. Larionova, Systemic risks of the Russian banking sector: assessment and regulation methods, Financial University Press, 2013. No. 1, pp. 27-34.

[15] M. V. Leonov, Special aspects of functioning and activity of bank conglomerates in Russia // Volgograd University Press. Ser. 3, Econ. Ecol. 2014. No. 2 (25), pp. 62-69.

[16] D. F. Zakirova, E. F. Zakirova, Theoretical issues of credit risk concentration management in commercial banks // Gazette on Economics, Law and Sociology. 2016. No. 3, pp. 33-37.

[17] P. A. Razumovsky, M. V. Pomazanov, Penalty on the capital for credit risk concentration // Banking Business, 2010, No. 2, pp. 52-59.

[18] T. L. Zhuravlyova, M. V. Leonov, Russian banking system in recent years: general and regional approach // Financial magazine. 2015. No. 6, pp. 47-58

[19] I. E. Timoshenko, Assessment of risk of sectoral loan portfolio concentration in a commercial bank // Siberian Financial School. 2009. No. 4, pp. 112-115.

[20] S. V. Murzayev, Lending funds to related borrowers as a loan portfolio risk concentration factor // Actual Problems of Economics and Law. 2013. No. 2. P. 132-139.

[21] Yu. A. Slesar, Risks of concentration, measurement, management and control // Financial Risk Management, 2009, No. 04(20), pp. 280-295. 
[22] Measuring and controlling large credit exposures, Basel Committee on Banking Supervision, 1991, URL: http://www.bis.org/publ/bcbsc121.pdf

[23] Standards supervisory framework for measuring and controlling large exposures

[24] Basel Committee on Banking Supervision, April 2014, URL: http://www.bis.org/pub1/bcbs283.pdf. 